\title{
ANALISIS KEMUNCULAN SIKAP SPIRITUAL DAN SIKAP SOSIAL DALAM KEGIATAN PEMBELAJARAN IPA KELAS IV SD YANG MENGGUNAKAN KTSP DAN KURIKULUM 2013
}

\author{
Evi Gusviani ${ }^{1}$
}

\begin{abstract}
ABSTRAK
Dewasa ini, dekadensi moral merupakan hal yang memerlukan penanganan serius mengingat pembentukan watak dan martabat bangsa bergantung pada pembentukan pribadi dari manusia itu sendiri. Upaya yang dapat dilakukan dalam lingkungan pendidikan yaitu membina karakter peserta didik dengan mengembangkan sikap spiritual dan sosial yang dijadikan komponen dalam penelitian ini. Tujuan penelitian ini adalah mendeskripsikan kemunculan sikap spiritual dan sosial pada kegiatan pembelajaran IPA kelas IV SD yang menggunakan KTSP dan Kurikulum 2013. Penelitian ini dilakukan secara kualitatif dengan metode deskriptif dan teknik purposive sampling. Instrumen yang digunakan berupa observasi kegiatan pembelajaran untuk menganalisis kemunculan sikap spiritual dan sosial menggunakan videograph. Berdasarkan hasil perhitungan total rata-rata kemunculan sikap spiritual dan sosial diperoleh SD yang menggunakan Kurikulum 2013 mendapatkan hasil yang lebih besar. Diharapkan dari penelitian ini dapat dijadikan sebagai dasar bagi penelitian selanjutnya dan sebagai motivasi bagi guru untuk dapat memunculkan sikap spiritual dan sikap sosial, khususnya dalam pembelajaran IPA.
\end{abstract}

Kata kunci: sikap spiritual, sikap sosial, KTSP, dan Kurikulum 2013

\section{A. PENDAHULUAN}

Pendidikan dianggap sebagai aspek yang memiliki peranan penting dalam membentuk generasi bangsa agar tidak kehilangan pegangan tradisi dan budaya yang sesuai dengan falsafah bangsa Indonesia. Oleh karena itu instrumen yang paling strategis dalam mengembangkan kehidupan manusia ke arah yang lebih baik adalah melalui peningkatan kualitas pendidikan yang dijadikan sebagai wacana pembangunan bangsa.

Undang-Undang Nomor 20 tahun 2003 tentang Sistem Pendidikan Nasional Bab II pasal 3 menjelaskan fungsi dan tujuan pendidikan nasional. Dapat kita artikan bahwa pendidikan tidak hanya membentuk insan yang cerdas semata tetapi berkepribadian (berkarakter) sehingga akan lahir generasi bangsa yang tumbuh dan berkembang dengan karakter yang bernafaskan nilai-nilai luhur bangsa dan agama. Selanjutnya lampiran Undang-Undang Nomor 17 Tahun 2007 tentang Rencana Jangka Panjang Nasional tahun 2005 - 2025 menyatakan bahwa, upaya untuk

${ }^{1}$ Universitas Pendidikan Indonesia 
membangun kualitas manusia tetap menjadi perhatian penting. Pembangunan jati diri bangsa Indonesia, seperti penghargaan pada nilai budaya dan bahasa, nilai solidaritas sosial, kekeluargaan, dan rasa cinta tanah air dirasakan makin memudar. Hal tersebut disebabkan antara lain, karena belum optimalnya upaya pembentukan karakter bangsa, kurangnya keteladanan para pemimpin, lemahnya budaya patuh pada hukum, cepatnya penyerapan budaya global yang negatif, dan kurang mampunya menyerap budaya global yang lebih sesuai dengan karakter bangsa, serta ketidakmerataan kondisi sosial dan ekonomi masyarakat. Ditambah lagi dengan pemberitaan media baik cetak maupun elektronik yang tidak mendidik, ditengarai berpengaruh negatif terhadap perkembangan karakter dan pencapaian hasil belajar peserta didik. Atas dasar hal tersebut pendidikan karakter seharusnya dapat dijadikan sebagai upaya untuk melakukan internalisasi sikap dan perilaku terpuji sesuai dengan norma-norma yang dapat dijadikan sebagai pendidikan budi pekerti plus yang melibatkan pengetahuan, perasaan dan tindakan. Hasil penelitian Yayasan Kita dan Buah Hati tahun 2010 yang diakses dari berita on line (detik.com dan viva.co.id) menyebutkan sebanyak $67 \%$ dari 2.818 siswa kelas 4,5, dan 6 di wilayah Jabodetabek mengaku pernah mengakses informasi pornografi. Proporsi dari jumlah tersebut adalah $24 \%$ mengaku melihat pornografi melalui media komik, 22\% melalui internet, $17 \%$ melalui games, 12\% melalui film, dan 6\% melalui telepon genggam. April 2013, sebanyak 5 siswa SD di Gowa, Sulawesi Selatan tega memperkosa temannya sendiri karena terinspirasi film porno. Pada bulan Mei 2013 seorang siswa perempuan dari salah satu SD di Medan yang masih duduk di kelas 1 menjadi korban pemerkosaan 3 temannya yang juga masih duduk di bangku SD (detik.com, 2013).

Hasil pendidikan di sekolah saat ini hanya mampu menghasilkan insan-insan yang kurang memiliki kesadaran diri termasuk sikap spiritual dan sikap sosial, serta kurang mampu berkomunikasi secara luwes dengan lingkungan pembelajaran dan kehidupan sosial masyarakat. Hal ini tampaknya tidak berlebihan jika bangsa Indonesia selama ini digambarkan sebagai bangsa yang mengalami penurunan kualitas karakter bangsa. Meski anggapan tersebut tidak selalu benar, tetapi pada sisi yang lain tampaknya perlu diakui bahwa karakter kita sampai saat ini masih hanya sekedar mengantarkan peserta didik untuk memahami suatu konsep sementara dalam tataran aplikasi belum sepenuhnya ditekankan. Sebagaimana disinyalir Tilaar (2012, hlm.89), bahwa pelaksanaan pendidikan karakter bangsa di sekolah-sekolah kurang memberi ruang bagi tumbuhnya nilai-nilai karakter siswa sebagai upaya penguatan jati diri dalam mempersiapkan generasi bangsa menuju sukses Indonesia Emas Tahun 2025.

Memperhatikan beberapa alasan di atas maka dikembangkannya nilai-nilai karakter pada diri siswa meliputi: religius, jujur, toleransi, disiplin, kerja keras, kreatif, mandiri, demokratis, rasa ingin tahu, semangat kebangsaan, cinta tanah air, menghargai prestasi, bersahabat/komunikatif, cinta damai, gemar membaca, peduli lingkungan, peduli sosial, dan tanggung jawab (Ghozi, 2010, hlm.26). Upaya mewujudkan nilai-nilai karakter tersebut dapat dilaksanakan melalui pembelajaran di setiap bidang studi di sekolah dengan proses kehidupan bangsa baik di lingkungan 
keluarga, di sekolah maupun di masyarakat. Tentunya proses belajar dan pembelajaran yang demikian menuntut adanya pendidik atau guru yang dapat memfasilitasi dan mengadopsi semua nilai-nilai karakter bangsa yang akan dibangun.

Sikap spiritual dan sikap sosial adalah salah satu aspek penting yang perlu dihadirkan dalam proses pembelajaran khususnya IPA. Sikap spiritual adalah sikap yang menyangkut moral yang mampu memberikan pemahaman untuk membedakan sesuatu yang benar dan yang salah berdasarkan keimanan dan ketakwaan kepada Tuhan YME. Sedangkan sikap sosial adalah sikap yang menyangkut kehidupan sosial sebagai bentuk interaksi siswa dengan alam, lingkungan sekolah dan lingkungan sekitar. Menurut Fathurrohman et al, (2013, hlm. 130) "kemampuan siswa pada suatu jenjang pendidikan mencakup tiga domain, yaitu kemampuan berpikir (kognitif), keterampilan melakukan pekerjaan (psikomotor), dan perilaku (afektif)". Setiap siswa memiliki potensi pada ketiga domain tersebut, namun tingkatannya satu sama lain berbeda. Hal ini menunjukkan bahwa setiap manusia memiliki potensi yang berbeda dan dapat dikembangkan menjadi kemampuan untuk hidup di masyarakat. Domain afektif lebih difokuskan pada pembentukan sikap spiritual dan sikap sosial memang sangat penting bagi semua orang, namun kedua aspek tersebut tidak mudah dilakukan. Selain itu memerlukan kemampuan yang khusus dan tidak semua orang dapat meraihnya. Dengan demikian, kegiatan pembelajaran IPA tidak hanya menekankan pada pencapaian kompetensi saja, akan tetapi lebih dari itu dapat menumbuhkan pembentukan pribadi/karakter peserta didik.

\section{B. METODE PENELITIAN}

Penelitian ini menggunakan pendekatan kualitatif dengan metode deskriptif. Instrumen penelitian adalah observasi kemunculan sikap spiritual dan sikap sosial dalam pembelajaran IPA. Subjek dalam penelitian ini adalah empat orang guru, di mana dua guru yang mengajar di SD yang menggunakan KTSP dan dua orang guru yang mengajar di SD yang menggunakan Kurikulum 2013. Adapun analisis data dalam penelitian ini dilakukan dengan menggunakan software videograph, dengan software ini peneliti dibantu untuk menganalisis kemunculan sikap spiritual dalam pembelajaran, dengan cara memasukkan aspek dan indikator ke dalam kolom kriteria kemudian melakukan koding dengan cara menandai kriteria yang muncul dalam rentang waktu 20 detik. Hasil koding di eksport ke SPSS versi 20 sehingga menghasilkan tabulasi koding. Setelah itu dilakukan analyze untuk menghasilkan data koding dalam bentuk tabel frekuensi dan persen serta diagram lingkaran.

\section{HASIL PENELITIAN}

Penelitian di SD yang menggunakan KTSP pembelajaran diamati sebanyak tiga pertemuan (210 menit) dengan rincian dua jam pelajaran pada setiap pertemuan, guru yang mengajar diberi kode G1 dan G2. Penelitian di SD yang menggunakan Kurikulum 2013, pembelajaran yang diamati sebanyak lima pertemuan (900 menit) 
dengan rincian enam jam pembelajaran pada setiap pertemuan, guru yang mengajar diberi kode G3 dan G4.

\section{Kemunculan Sikap Spiritual}

Tabel 1 Kemunculan Sikap Spiritual oleh Guru Kelas IV di SD yang Menggunakan KTSP dan Kurikulum 2013

\begin{tabular}{|c|c|c|c|c|c|c|c|c|c|}
\hline \multirow{3}{*}{ No } & \multirow{3}{*}{ Komponen Sikap Spiritual } & \multicolumn{4}{|c|}{ KTSP } & \multicolumn{4}{|c|}{ Kurikulum 2013} \\
\hline & & \multicolumn{2}{|c|}{ G1 } & \multicolumn{2}{|c|}{ G2 } & \multicolumn{2}{|c|}{ G3 } & \multicolumn{2}{|c|}{ G4 } \\
\hline & & menit & $(\%)$ & menit & $(\%)$ & menit & $(\%)$ & menit & $(\%)$ \\
\hline 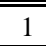 & " Menghargai ajaran agama yang dianut & 1,00 & 0,80 & "0 & "0 & 5,67 & $1,1,30$ & 2,00 & 0,20 \\
\hline 2 & Menghayati ajaran agama yang dianut & 1,67 & 1,40 & 0 & 0 & 8,00 & 1,80 & 2,33 & 0,30 \\
\hline 3 & Mengamalkan ajaran agama yang dianut & 1,33 & 1,10 & 0 & 0 & 7,00 & 1,60 & 0 & 0 \\
\hline \multicolumn{2}{|r|}{ Jumlah } & 4,00 & 3,30 & 0 & 0 & 20,67 & 4,70 & 4,33 & 0,50 \\
\hline \multicolumn{2}{|r|}{ Rata-rata } & 1,33 & 1,10 & 0 & $\mathbf{0}$ & 6,89 & 1,57 & 1,44 & $\mathbf{0 , 1 7}$ \\
\hline & ata-rata berdasarkan kurikulum (\%) & & & & & \multicolumn{4}{|c|}{0,87} \\
\hline
\end{tabular}

Berdasarkan hasil rekapitulasi pada Tabel 1 di atas dapat diketahui bahwa kemunculan sikap spiritual tidak semua dimunculkan oleh SD yang menggunakan KTSP maupun Kurikulum 2013. Peneliti melakukan pengamatan terhadap G1, G2, G3, dan G4 dalam kegiatan pembelajaran, ternyata temuannya lebih banyak pada sekolah yang menggunakan Kurikulum 2013 memperoleh rata-rata sebesar 0,87\% sedangkan sekolah yang menggunakan KTSP memperoleh hasil 0,55\%.

\section{Kemunculan Sikap Sosial}

Penelitian yang dilakukan dalam melihat kemunculan sikap sosial dari guru pada SD yang menggunakan KTSP dan Kurikulum 2013 mencakup tujuh komponen sikap sosial, yaitu : 1) Jujur; 2) Disiplin; 3) Tanggung jawab; 4)Toleransi; 5) Gotomg Royong; 6) Sopan santun; dan 7) Percaya diri

Tabel 2 Kemunculan Sikap Sosial pada Guru Kelas IV SD yang Menggunakan KTSP dan Kurikulum 2013

\begin{tabular}{|c|l|c|c|c|c|c|c|c|c|}
\hline \multirow{2}{*}{ No } & \multirow{2}{*}{ Komponen \& Indikator Sikap Sosial } & \multicolumn{4}{|c|}{ KTSP } & \multicolumn{4}{c|}{ Kurikulum 2013 } \\
\cline { 3 - 11 } & & \multicolumn{2}{|c|}{ G1 } & \multicolumn{2}{|c|}{ G2 } & \multicolumn{2}{|c|}{ G3 } & \multicolumn{2}{c|}{ G4 } \\
\cline { 3 - 11 } & & menit & $(\%)$ & menit & $(\%)$ & menit & $(\%)$ & menit & $(\%)$ \\
\hline \hline 1 & \multirow{2}{*}{ Jujur } & 2,33 & 1,90 & 1,33 & 0,60 & 14,00 & 4,30 & 7,67 & 1,10 \\
\hline 2 & Disiplin & 16,00 & 13,1 & 34,67 & 15,10 & 42,67 & 13,00 & 49,00 & 7,10 \\
\hline 3 & Tanggung jawab & 10,00 & 8,30 & 6,00 & 2,60 & 28,00 & 8,50 & 33,67 & 4,90 \\
\hline 4 & Toleransi & 0 & 0 & 6,00 & 2,60 & 30,00 & 9,20 & 17,33 & 2,59 \\
\hline 5 & Gotong royong & 3,33 & 2,70 & 0,67 & 0,20 & 4,33 & 1,30 & 12,67 & 1,80 \\
\hline 6 & Sopan atau santun & 1,00 & 0,80 & 5,67 & 2,50 & 20,67 & 6,30 & 8,00 & 1,20 \\
\hline 7 & Percaya diri & 18,00 & 14,80 & 40,67 & 17,80 & 62,67 & 19,10 & 69,00 & 10,00 \\
\hline \hline \multirow{2}{*}{ Jumlah } & 50,66 & 41,60 & 95,01 & 41,40 & 202,34 & 61,70 & 197,64 & 28,69 \\
\hline \multirow{2}{*}{ Rata-rata } & 7,24 & $\mathbf{5 , 9 4}$ & 13,57 & $\mathbf{5 , 9 1}$ & 28,90 & $\mathbf{8 , 8 1}$ & 28,19 & $\mathbf{4 , 1 0}$ \\
\hline
\end{tabular}




\begin{tabular}{|c|c|c|c|c|c|c|c|c|c|}
\hline \multirow{2}{*}{ No } & \multicolumn{4}{|c|}{ KTSP } & \multicolumn{3}{c|}{ Kurikulum 2013 } \\
\cline { 3 - 9 } & & \multicolumn{2}{|c|}{ Komponen \& Indikator Sikap Sosial } & \multicolumn{2}{|c|}{ G2 } & \multicolumn{2}{|c|}{ G3 } & \multicolumn{2}{|c|}{ G4 } \\
\cline { 3 - 9 } & & menit & $(\%)$ & menit & $(\%)$ & menit & $(\%)$ & menit & $(\%)$ \\
\hline \hline
\end{tabular}

Berdasarkan Tabel 2 dapat diketahui bahwa kemunculan sikap sosial lebih banyak dimunculkan oleh sekolah yang menggunakan Kurikulum 2013, dengan rata-rata kemunculan sebesar 6,46\% sedangkan untuk KTSP sebesar 5,93\%.

\section{PEMBAHASAN}

Hasil penelitian menunjukkan pada SD yang menggunakan Kurikulum 2013 memperoleh hasil yang lebih besar, hal ini sesuai dengan esensi Kurikulum 2013 di mana aktivitas pembelajaran didesain dalam bentuk tiga ranah (sikap, pengetahuan dan keterampilan), di mana komponen sikap terbagi menjadi dua, yaitu sikap spiritual (KI-1) dan sikap sosial (KI-2). Pada Kurikulum 2013 menempatkan sikap spiritual dan sikap sosial pada urutan pertama dan kedua, hal ini dimaknai bahwa Kurikulum 2013 sangat memberi penekanan pada pengembangan karakter dan kepribadian siswa. Selain itu pengembangan sikap spiritual dan sikap sosial harus mendasari pengembangan pengetahuan dan keterampilan. Pada Kurikulum 2013 ranah sikap spiritual dan sikap sosial memegang peranan yang amat penting dalam melahirkan generasi muda yang berakhlak mulia. Pendidikan seharusnya mampu memberikan pencerahan dan menumbuhkan karakter yang baik kepada siswa sehingga mereka mampu bersikap responsif terhadap segala persoalan yang tengah dihadapi masyarakat, bangsa dan negara. Melalui pencerahan yang berhasil diperolehnya, siswa diharapkan dapat menjadi sosok spiritual dan sosial yang memiliki apresiasi tinggi terhadap masalah-masalah yang menimpa bangsa ini, seperti kemanusiaan, korupsi, toleransi, demokratisasi, dan kedamaian hidup.

Ini bukan berarti SD yang menggunakan KTSP tidak penting dalam memunculkan sikap spiritual dan sikap sosial, sebagai pengembangan nilai-nilai karakter peserta didik, sangat dimungkinkan dalam proses kegiatan pembelajaran guru memberikan stimulus berupa sikap spiritual dan sikap sosial yang akan menjadi fondasi bagi pembentukan moral peserta didik. Hal ini tentu saja sesuai dengan Undang-Undang Nomor 20 tahun 2003 tentang Sistem Pendidikan Nasional Bab II pasal 3 menjelaskan fungsi dan tujuan pendidikan nasional. Di mana pendidikan nasional berfungsi mengembangkan kemampuan dan membentuk watak serta peradaban bangsa yang bermartabat dalam rangka mencerdaskan kehidupan bangsa. Sedangkan tujuan pendidikan nasional untuk mengembangkan potensi peserta didik agar menjadi manusia yang beriman dan bertakwa kepada Tuhan YME, berakhlak mulia, sehat, berilmu, cakap, kreatif, mandiri, dan menjadi warga negara yang demokratis serta bertanggung jawab. Rumusan tujuan tersebut disinyalir oleh Tilaar (2012, hlm.89), bahwa pelaksanaan pendidikan karakter bangsa di sekolah-sekolah kurang memberi ruang bagi tumbuhnya nilai-nilai karakter siswa sebagai upaya 
penguatan jati diri dalam mempersiapkan generasi bangsa yang bermartabat. Selain itu dalam PP Nomor 19 Tahun 2005 tentang Standar Nasional Pendidikan yang di dalamnya terdapat SKL pada jenjang pendidikan dasar bertujuan untuk meletakkan dasar kecerdasan, pengetahuan, kepribadian, akhlak mulia serta keterampilan untuk mandiri dan pendidikan lebih lanjut. Dimana sosok manusia Indonesia lulusan dari jenjang pendidikan dasar seharusnya memiliki ciri sebagai berikut: 1) Tumbuh keimanan dan ketakwaan terhadap Tuhan YME; 2) Tumbuh sikap beretika ( sopan santun dan beradab); 3) Tumbuh penalaran yang baik (mau belajar, ingin tahu, senang membaca, memiliki inovasi, berinisiatif dan bertanggung jawab); 4) Tumbuh kemampuan komunikasi/sosial (tertib, sadar aturan, dapat bekerja sama dengan teman, dapat berkompetisi); 5) Tumbuh kesadaran untuk menjaga kesehatan badan.

Selaras dengan hal tersebut, Buchori (dalam Fathurrohman, et. al, 2013), pendidikan karakter seharusnya membawa peserta didik ke pengenalan nilai secara kognitif, penghayatan nilai secara afektif dan akhirnya ke pengamalan nilai secara nyata sehingga pada dasarnya pendidikan karakter dapat diintegrasikan dalam pembelajaran pada setiap mata pelajaran, termasuk IPA. Pendidikan merupakan usaha suatu masyarakat dan bangsa dalam mempersiapkan generasinya untuk menghadapi tantangan demi keberlangsungan hidup di masa depan (Ghozi, 2010, hlm.26). Nilainilai karakter bangsa esensial dikembangkan pada siswa. Hal ini menegaskan bahwa nilai karakter sebagai landasan legal formal untuk tujuan pendidikan dalam ketiga ranah (sikap, pengetahuan dan keterampilan) yang melibatkan aspek sikap spiritual dan sikap sosial sebagai rujukan utama untuk penyelenggaraan pembelajaran bidang studi apapun, yang selain memuat kemampuan kognitif juga menekankan pada pembentukan dan pengembangan pribadi, sikap dan watak peserta didik. Implikasi dari Undang-Undang tersebut bahwa, pendidikan di setiap jenjang, termasuk Sekolah Dasar (SD) harus diselenggarakan secara terprogram dan sistematis mengarah kepada pencapaian tujuan pendidikan nasional.

Kusrahmadi (2007) menyatakan bahwa pendidikan tidak semata-mata mentransfer ilmu pengetahuan kepada peserta didik, tetapi juga mentransfer nilainilai moral dan nilai-nilai kemanusiaan yang bersifat universal. Dengan transfer moral bersifat universal, diharapkan peserta didik dapat menghargai kehidupan orang lain tercermin dalam tingkah laku serta aktualisasi diri, semenjak usia SD hingga kelak dewasa menjadi warga negara yang baik. Pendidikan moral akan berhasil apabila guru memberi stimulus agar anak didik memberi respon sesuai dengan keinginan pendidik, dan dengan stimulus, respon itu anak didik diberi classical conditioning untuk menciptakan kondisi belajar yang kondusif. Proses stimulus dan respon dalam pendidikan moral harus diberikan terus menerus dan terprogram, sehingga anak SD akan memiliki habitus (perubahan perilaku) dalam mewujudkan manusia Indonesia yang bermoral.

Pendapat Amri, et. al. (2011, hlm.141) pada tingkat SD sejumlah kemampuan dasar untuk keperluan pengembangan pribadi seperti kemampuan membaca, menulis, berpikir kritis serta keberanian mengeluarkan gagasan dan bekerja sama perlu ditonjolkan. Hal ini berarti komponen afektif memegang peranan yang lebih besar 
pada tingkat SD guna pembentukan karakter siswa. Pada kenyataanya pengembangan dan implementasi KTSP masih cenderung terpusat pada pengembangan kemampuan intelektual siswa dan belum menyentuh ranah karakter yang sangat penting sebenarnya untuk membentuk moral bangsa. Pada jenjang SD sudah sepantasnya siswa tidak hanya dicekoki dengan berbagai disiplin ilmu yang hanya terserap otak dan tuntutan untuk memperoleh nilai yang bagus dari guru dan orang tua. Hal ini dapat dilihat pada grafik Keseimbangan antara Sikap, Keterampilan dan Pengetahuan untuk membangun Soft Skills dan Hard Skills di bawah ini:

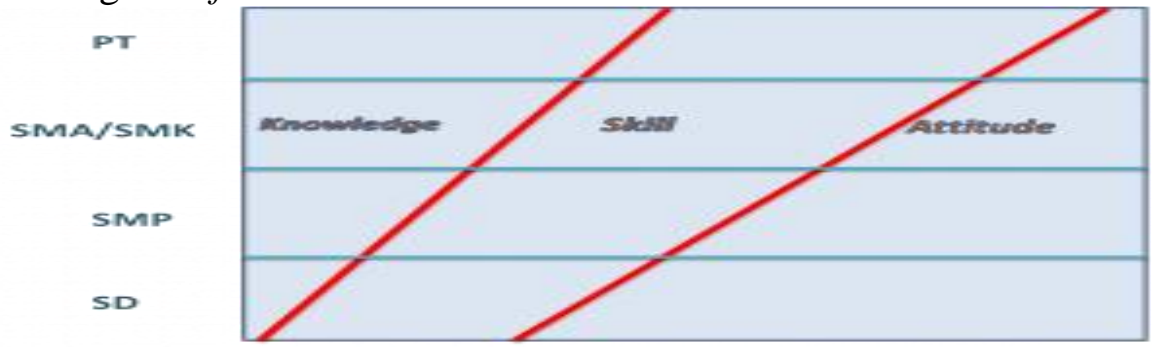

Sumber: Marzano (1985), Bruner (1960)

Grafik di atas menunjukkan bahwa pembentukan aspek afektif (sikap) dan psikomotorik (keterampilan) mempunyai porsi yang lebih besar sehingga sangat penting ditanamkan pada siswa SD dibanding aspek kognitif (pengetahuan). Hal ini juga didukung dengan PP Nomor 19 Tahun 2005 tentang Standar Nasional Pendidikan yang di dalamnya terdapat SKL pada jenjang pendidikan dasar bertujuan untuk meletakkan dasar kecerdasan, pengetahuan, kepribadian, akhlak mulia serta keterampilan untuk mandiri dan pendidikan lebih lanjut.

Berdasarkan hal di atas pendidikan sains/IPA pun harus mampu menanamkan nilai-nilai agama dan nilai-nilai luhur budaya bangsa termasuk sikap sosial sebagaimana yang dikemukakan Einstein dalam Yudianto (2005, hlm.14) tentang kandungan nilai-nilai dalam sains mencakup nilai praktis, intelektual, pendidikan, sosial-politik-ekonomi, dan nilai religius. Nilai-nilai intrinsik sains adalah nilai-nilai yang dimiliki oleh sains itu sendiri, dan bukan dampak dari sains terhadap kehidupan manusia. Berdasarkan pandangan ini, pembelajaran sains pun tidak hanya memahami apa, mengapa, dan bagaimana sains itu, tetapi juga harus dapat menanamkan nilainilai tersebut untuk pembelajaran manusia.

Kaitan pembelajaran IPA dengan sikap spiritual dan sikap sosial pada materi SDA, yaitu pembelajaran IPA haruslah mencakup aspek-aspek kognitif, psikomotor, dan afektif di mana interaksi ketiga aspek tersebut diharapkan dapat membentuk kreativitas siswa. Pengembangan sikap dan perilaku kreatif bagi siswa sangatlah penting karena hasil utama dari suatu proses pendidikan adalah perubahan sikap dan tingkah laku dari siswa. IPA khususnya pada materi SDA dapat digunakan sebagai media berpikir untuk membaca tanda-tanda kebesaran Tuhan YME dengan perumpamaan segala sesuatu yang tampak di muka bumi ini, seperti sungai, danau, sumber daya laut, pantai, hasil tambang dan lain-lain. Mengaitkan pembelajaran IPA dengan aspek ke-Tuhanan akan membawa dampak positif bagi siswa, di antaranya 
menghindari tawuran antar pelajar ataupun meningkatkan iman dan takwa dari siswa itu sendiri. Sikap spiritual seharusnya menjadi fondasi pembentukan karakter di usia SD. Untuk itu diharapkan ke depannya para pengajar IPA dapat memberikan alternatif pembelajaran IPA yang berkonsep spiritual. Begitu jug dengan menanamkan sikap sosial dalam pembelajaran IPA. Menurut Yani (2014, hlm. 55) bahwa sikap sosial merupakan perwujudan eksistensi kesadaran dalam upaya mewujudkan harmoni kehidupan. Kurikulum 2013 adalah kurikulum yang sarat dengan pendidikan karakter di mana isi dari sikap sosial berasal dari butir-butir pendidikan karakter yang telah disosialisasikan sejak 2010. Salah satu redaksi KI-2, misalnya berbunyi: "menghayati dan mengamalkan perilaku jujur, disiplin, tanggung jawab, peduli (gotong royong, kerjasama, toleran, damai), santun, responsif dan proaktif dan menunjukkan sikap sebagai bagian solusi atas berbagai permasalahan dalam berinteraksi secara efektif dengan lingkungan sosial dan alam serta dalam menempatkan diri sebagai cerminan bangsa dalam pergaulan dunia”.

Kemunculan sikap spiritual dan sikap sosial yang dimunculkan tiap-tiap guru berbeda. Hal ini bergantung pada kepiawaian guru dalam mengemas pembelajaran sehingga apa yang disampaikan mengandung unsur "sikap spiritual" dan "sikap sosial" yang dapat menjadi fondasi dalam membentuk karakter siswa yang berKetuhanan YME dan dapat bersosialisasi sehingga dapat menyesuaikan diri sesuai dengan perkembangan jaman. Sikap spiritual dapat dimunculkan dalam pembelajaran terutama pada kegiatan awal dengan membiasakan siswa untuk berdo'a sebelum belajar, memberikan motivasi pada siswa; pada kegiatan inti guru dapat memberikan stimulus pada siswa untuk membangkitkan sikap spiritual dengan mengaitkan pembelajaran terhadap aspek ke-Tuhanan dan pada bagian penutup dengan memberikan nasihat atau pesan moral kepada siswa yang berhubungan dengan aspek spiritual. Sikap sosial dapat lebih dimunculkan dalam kegiatan inti. Guru dapat lebih mengeksplorasi dan membangkitkan sikap sosial siswa dalam pembelajaran dengan kemunculan yang beragam namun hal ini juga bergantung dengan waktu pertemuan dan kepiawaian guru itu sendiri. Selain itu sikap sosial dapat dimunculkan oleh guru pada akhir pembelajaran dengan memberikan nasihat atau motivasi agar siswa dapat membentuk pribadi yang memiliki sikap sosial yang baik sebagai bekal hidup di masyarakat. Komponen-komponen tersebut dapat dituangkan dalam Rencana Pelaksanaan Pembelajaran (RPP) sehingga proses pembelajaran lebih terarah dan mencapai tujuan yang diharapkan.

Sikap spiritual menurut amanah Depdiknas (2007, hlm.13) poin ke-1 bahwa setelah melaksanakan pembelajaran siswa harus memperoleh keyakinan terhadap kebesaran Tuhan YME berdasarkan keberadaan, keindahan dan keteraturan alam ciptaan-Nya dan pada poin ke-6 meningkatkan kesadaran untuk menghargai alam dan segala keteraturannya sebagai salah satu ciptaan Tuhan YME. Sedangkan menurut SKL SD Depdiknas-BSNP (2007, hlm. 2) poin ke-1 bahwa setelah melaksanakan pembelajaran siswa harus menjalankan ajaran agama yang dianut sesuai dengan tahap perkembangan anak (mencakup menghargai, menghayati, dan mengamalkan). Pada Kurikulum 2013, sikap spiritual tercantum dalam Kemendikbud (2013) tentang KI-1 
yang terdiri atas menerima, menjalankan, menghayati, menghargai, dan mengamalkan ajaran agama yang dianutnya. Namun yang menjadi fokus penelitian ini adalah aspek menghayati, menghargai, dan mengamalkan. Menurut peta kompetensi yang arus dicapai seperti yang tercantum dalam Kemendikbud (2013) bahwa setelah memperoleh pembelajaran siswa harus bertambah keimanannya dengan menyadari hubungan keteraturan dan kompleksitas alam dan jagat raya terhadap kebesaran Tuhan yang menciptakannya dalam pengamalan ajaran agama yang dianutnya. Sedangkan berdasarkan SKL SD Kurikulum 2013 Kemendikbud (2014) tentang sikap, bahwa setelah melaksanakan pembelajaran siswa diharapkan memiliki perilaku yang mencerminkan sikap orang beriman, berakhlak mulia, berilmu, percaya diri, dan bertanggung jawab dalam berinteraksi secara efektif dengan lingkungan sosial dan alam di lingkungan rumah, sekolah, dan tempat bermain. Berdasarkan hal di atas, G1 dalam proses pembelajaran selama tiga kali pertemuan menunjukkan kemunculan sikap spiritual dengan jumlah sebesar 3,30\% atau selama 4 menit. Melihat dari kemunculan sikap spiritual dalam pembelajaran yang dilakukan oleh G1 apabila dihubungkan dengan SKL maka G1 mampu memunculkan semua sikap spiritual yang diamanahkan oleh SKL.

G2 tidak memunculkan sikap spiritual dalam proses pembelajaran. Hal ini dikarenakan G2 hanya terfokus pada materi pembelajaran yang terdapat pada buku ajar. Hal tersebut tidak sejalan dengan tujuan dan skenario pembelajaran dalam RPP. G2 perlu mencantumkan bentuk sikap spiritual yang lain dalam RPP sehingga tidak hanya memunculkan aspek menghargai SDA ciptaan Tuhan YME dalam bentuk tindakan membersihkan lingkungan sekitar.

G3 dalam memunculkan sikap spiritual pada proses pembelajaran selama lima kali pertemuan menunjukkan total kemunculan sikap spiritual sebesar 4,70\% atau selama 20,67 menit. Kemunculan ini lebih banyak dibandingkan dengan kemunculan yang dilakukan oleh G4 yang sama-sama menggunakan Kurikulum 2013 maupun G1 dan G2 yang menggunakan KTSP. Adapun aspek yang dimunculkan oleh G3 yaitu menghargai ajaran agama yang dianut (5,67 menit), menghayati ajaran agama yang dianut ( 8 menit), dan mengamalkan ajaran agama yang dianut ( 7 menit). Melihat dari kemunculan sikap spiritual yang dimunculkan G3 yang dihubungkan dengan SKL, G3 mampu memunculkan semua sikap spiritual yang diamanahkan oleh SKL. Hal tersebut tidak sejalan dengan tujuan dan skenario pembelajaran dalam RPP, di mana dalam RPP G3 hanya memunculkan aspek menghargai SDA ciptaan Tuhan YME dalam bentuk tindakan menjaga dan memelihara SDA di lingkungan sekitar sebagai ciptaan Tuhan YME, dan menghayati SDA ciptaan Tuhan YME dalam bentuk bersyukur kepada Tuhan YME

G4 dalam memunculkan sikap spiritual pada proses pembelajaran selama lima kali pertemuan menunjukkan kemunculan sikap spiritual dengan total kemunculan selama 4,33 menit. G4 lebih banyak memunculkan sikap spiritual dibandingkan dengan kemunculan yang dilakukan oleh G1 dan G2 yang menggunakan KTSP, yaitu 4 menit dan 0. Adapun aspek yang dimunculkan oleh G4 yaitu menghargai ajaran agama yang dianut (2 menit), menghayati ajaran agama yang dianut (2,33 menit), dan 
mengamalkan ajaran agama yang dianut (0). Tetapi bila dibandingkan dengan G3 yang sama-sama menggunakan Kurikulum 2013 G4 lebih sedikit memunculkan sikap spiritual dalam pembelajaran. Hal ini dikarenakan G4 kurang memberikan stimulus atau arahan pada siswa agar siswa dapat berpikir dan bersikap secara spiritual sehingga hal tersebut akan terbawa dalam kehidupan siswa sehari-hari. Melihat dari kemunculan sikap spiritual di sekolah G4 yang dihubungkan dengan SKL, bahwa G4 cukup mampu memunculkan semua sikap spiritual yang diamanahkan oleh SKL terkecuali mengamalkan ajaran agama yang dianut. Dalam RPP juga G4 hanya memunculkan aspek menghargai SDA ciptaan Tuhan YME dalam bentuk tindakan menjaga dan memelihara SDA di lingkungan sekitar sebagai ciptaan Tuhan YME, dan menghayati SDA ciptaan Tuhan YME dalam bentuk bersyukur kepada Tuhan YME. Namun G4 perlu mengefektifkan waktu untuk memunculkan sikap spiritual dalam pembelajaran serta mencantumkan bentuk sikap spiritual di dalam RPP.

Berdasarkan amanah Depdiknas (2007, hlm. 13) poin ke-5 yang berhubungan dengan sikap sosial bahwa setelah melaksanakan pembelajaran siswa harus dapat meningkatkan kesadaran untuk berperan serta dalam memelihara, menjaga dan melestarikan lingkungan alam. Sikap sosial seperti yang tercantum dalam SKL-SD (Depdiknas, 2007, hlm.2) poin ke-3 mematuhi aturan-aturan sosial yang berlaku dalam lingkungannya, poin ke-5 menggunakan informasi tentang lingkungan sekitar sekitar secara logis, kritis dan kreatif, poin ke-7 menunjukkan rasa keingintahuan yang tinggi dan menyadari potensinya, poin ke-8 menunjukkan kemampuan memecahkan masalah sederhana dalam kehidupan sehari-hari, poin ke-9 menunjukkan kemampuan mengenali gejala alam dan sosial di lingkungan sekitar, poin ke-13 berkomunikasi secara jelas dan santun serta poin ke-14 bekerja sama dalam kelompok, tolong menolong, dan menjaga diri sendiri dalam lingkungan keluarga dan teman sebaya. Sikap sosial menurut amanah Kemendikbud (2013) tentang KI-2 yang menunjukkan perilaku ilmiah (memiliki rasa ingin tahu, obyektif, jujur, teliti, cermat, tekun, hati-hati, disiplin, tanggung jawab, terbuka dan peduli lingkungan) dalam aktivitas sehari-hari sebagai wujud implementasi sikap dalam melakukan inkuiri ilmiah dan berdiskusi. Sedangkan dalam SKL Kemendikbud (2014) tentang sikap maka diharapkan siswa memiliki perilaku mencerminkan sikap orang yang beriman, berakhlak mulia, berilmu, percaya diri, dan bertanggung jawab dalam berinteraksi dengan lingkungan sosial dan alam di lingkungan rumah, sekolah, dan tempat bermain. Setelah melihat penampilan G1 dalam proses pembelajaran selama tiga kali pertemuan menunjukkan rata-rata kemunculan sikap sosial sebesar $5,94 \%$, di mana hasil yang diperoleh G1 lebih besar dari G2 (5,91\%) yang sama-sama menggunakan KTSP.

G2 dalam memunculkan sikap sosial pada proses pembelajaran selama tiga kali pertemuan menunjukkan rata-rata kemunculan sikap sosial sebesar 5,91\% atau ratarata waktu kemunculan selama 13,57 menit. Melihat dari kemunculan sikap sosial yang dimunculkan G2 yang dihubungkan dengan SKL, G2 mampu memunculkan semua sikap sosial yang diamanahkan oleh SKL. Hal tersebut tidak sejalan dengan tujuan dan skenario pembelajaran dalam RPP, dimana dalam RPP G2 hanya 
memunculkan aspek toleransi dalam bentuk diskusi atau kerjasama secara berkelompok. G2 masih perlu banyak mengefektifkan waktu untuk memunculkan sikap sosial dalam pembelajaran serta mencantumkan bentuk sikap sosial di dalam RPP.

G3 dalam proses pembelajaran selama lima kali pertemuan menunjukkan kemunculan rata-rata sikap sosial sebesar $8,81 \%$ yang lebih besar dibandingkan dengan G4 yang sama-sama menggunakan Kurikulum 2013 (4,10\%). Hasil G3 juga lebih besar dari G1 dan G2 yang menggunakan KTSP. Adapun aspek yang dimunculkan yaitu jujur (4,30\%), disiplin (13,00\%), tanggung jawab $(8,50 \%)$, toleransi $(9,20 \%)$, gotong-royong $(1,30 \%)$, sopan atau santun $(6,30 \%)$ dan percaya diri $(19,10 \%)$. Hal ini dikarenakan G3 sering memunculkan sikap sosial dalam proses pembelajaran sehingga memicu siswa untuk terstimulus melakukan dan berpikir secara sosial.

G4 dalam proses pembelajaran selama lima kali pertemuan menunjukkan ratarata kemunculan sikap sosial sebesar $4,10 \%$. Hal ini dikarenakan G4 terkadang memunculkan sikap sosial dalam proses pembelajaran sehingga memicu siswa untuk terstimulus melakukan dan berpikir secara sosial. Melihat dari kemunculan sikap sosial di sekolah G4 yang dihubungkan dengan SKL, bahwa G4 mampu memunculkan semua sikap sosial yang diamanahkan oleh SKL. Hal tersebut tidak sejalan dengan tujuan dan skenario pembelajaran dalam RPP, dimana dalam RPP G4 hanya memunculkan beberapa aspek dari sikap sosial, seperti toleransi atau percaya diri. Namun guru tersebut masih perlu banyak mengefektifkan waktu untuk memunculkan sikap sosial dalam pembelajaran serta mencantumkan bentuk sikap sosial di dalam RPP.

\section{E. KESIMPULAN DAN SARAN \\ 1. Kesimpulan}

Berdasarkan hasil penelitan dan pembahasan yang telah dikemukan pada bab IV, dapat diambil kesimpulan sebagai berikut: kemunculan sikap spiritual dan sikap sosial lebih banyak dimunculkan oleh sekolah yang menggunakan Kurikulum 2013 dibandingkan dengan sekolah yang menggunakan KTSP. Hal tersebut sesuai dengan esensi Kurikulum 2013 dimana aktivitas pembelajaran didesain pada tiga ranah (sikap, pengetahuan dan keterampilan). Sikap spiritual perlu diterapkan sejak dini sebagai pondasi dalam mengurai segala permasalahan yang ada di dunia dengan selalu berpegang pada agama dan mengingat Tuhan Sang Pemilik segala-Nya. Adapun rata-rata kemunculan sikap spiritual untuk SD yang menggunakan KTSP adalah 0,55\% dan yang menggunakan Kurikulum 2013 adalah 0,87\%.

Pendidikan karakter untuk sikap sosial yang dikenal dengan KI-2, dimana sikap sosial diperlukan sebagai perwujudan eksistensi kesadaran dalam upaya mewujudkan harmoni kehidupan. Hasil rata-rata kemunculan sikap sosial pada SD yang menggunakan KTSP untuk sikap sosial sebesar 5,93\% sedangkan untuk SD yang 
menggunakan Kurikulum 2013 adalah 6,46\%. Adapun temuan hasil penelitian ini hanya berlaku pada subjek-subjek dalam penelitian ini.

\section{Saran}

Dari hasil penelitian yang telah dilakukan, dapat diajukan beberapa saran, antara lain; 1) Sebelum proses pembelajaran berlangsung guru hendaknya memahami tentang sikap spiritual dan sikap sosial, yaitu dengan cara menyusun komponen yang diharapkan muncul dalam pembelajaran, kemudian komponen tersebut dioperasionalkan ke dalam indikator dan tujuan pembelajaran. 2) Guru hendaknya dapat mengefektifkan waktu untuk memunculkan sikap spiritual dan sikap sosial dalam pembelajaran baik melalui KTSP maupun Kurikulum 2013, yaitu dengan cara menentukan komponen dan indikator yang akan dimunculkan dalam pembelajaran, kemudian indikator tersebut disubstitusikan ke dalam RPP dan menempatkannya pada waktu yang ditentukan sesuai dengan karakteristik kurikulum yang digunakan. 3) Guru hendaknya memahami cara menstimulus siswa dalam mengembangkan dan membangkitkan sikap spiritual dan sikap sosial, yaitu dengan cara memberikan stimulus atau motivasi spiritual dan sosial dalam pembelajaran yang dapat mempengaruhi kemampuan dan sikap siswa dalam kehidupan sehari-hari baik dipancing dengan pemberian problem solving, pertanyaan, maupun diajak untuk menganalisis tentang suatu sebab akibat yang diakhiri dengan penentuan sikap yang harus dimunculkan. 4) Diharapkan dapat dilakukan penelitian sikap spiritual dan sikap sosial dengan indikator-indikator yang masih dapat dikembangkan sehingga memperoleh hasil yang lebih luas yang dapat dijadikan sebagai dasar pengembangan dan penerapan sikap spiritual dan sikap sosial bagi siswa 5) Adanya pelatihan atau bimbingan secara berkesinambungan bagi guru mengenai bagaimana seorang guru dapat menstimulus siswa untuk berperilaku spiritual atau sosial sehingga dapat membentuk bangsa yang bermartabat.

\section{DAFTAR PUSTAKA}

Amri, et al. (2011). Implementasi Pendidikan Karakter Dalam Pembelajarannya. Jakarta: PT. Prestasi Pustakaraya.

BSNP. (2007). Standar Kompetensi dan Kompetensi Dasar Tingkat SD/MI. Jakarta: Departemen Pendidikan Nasional.

Depdiknas. (2007). Pedoman Penilaian Hasil Belajar di Sekolah Dasar. Jakarta: Depdiknas

Fathurrohman, et al. (2013). Pengembangan Pendidikan Karakter. Bandung: PT Refika Aditama.

Ghozi, A. (2010). Pendidikan Karakter dan Budaya Bangsa dan Implementasinya dalam Pembelajaran. Makalah disampaikan pada Pendidikan dan Pelatihan Tingkat Dasar Guru Bahasa Perancis Tanggal 24 Okober s.d 6 November 2010, hlm.26. 
Kemdikbud. (2013). Pedoman Pelatihan Guru dalam Kurikulum 2013. Jakarta: Kemdikbud

Kemdikbud. (2013). Tema 8. Indahnya Negeriku Kurikulum 2013. Jakarta: Kemdikbud

Kemdikbud. (2014). Pedoman Pelatihan Guru dalam Kurikulum 2013. Jakarta: Kemdikbud

Kemdikbud. (2014). SKL KI KD Kurikulum 2013 P4TKIPA. Bandung: Kemdikbud

Kusrahmadi, S, D. (2007). Pentingnya Pendidikan Moral Bagi Anak Sekolah Dasar. Dinamika Pendidikan No. 1/ Th. XIV/ Mei 2007.

Tilaar. (2012). Memantapkan Karakter Bangsa. Makalah disampaikan dalam Konverensi Nasional Pendidikan Indonesia Ke-VII Tanggal 1 November di UNY. Yogyakarta, hlm.89.

Yani, A. (2013). Mindset Kurikulum 2013. Bandung: Alfabeta. 